\title{
Electromyographic analysis of postural overload caused by bulletproof vests on public security professionals
}

\author{
Michele Caroline dos Santos ${ }^{1}$, Eddy Krueger ${ }^{1,2}$, Eduardo Borba Neves ${ }^{1,3 *}$ \\ ${ }^{1}$ Graduate Program in Biomedical Engineering, Federal Technological University of Paraná, Curitiba, PR, Brazil. \\ ${ }^{2}$ Neural Engineering and Rehabilitation Laboratory, Graduate Program in Rehabilitation Sciences, Anatomy Department, \\ State University of Londrina, Londrina, PR, Brazil. \\ ${ }^{3}$ Brazilian Army Research Institute of Physical Fitness, Rio de Janeiro, RJ, Brazil.
}

\begin{abstract}
Introduction: Military police activity individuals performing operational activity remain 12 hours using mandatory safety equipment. This work aimed to verify the electromyographic response in operational military police officers before and after a cycle of two working days. Methods: Forty-four male individuals were evaluated, with an average age of $34.59 \pm 8.05$. The used protocol consisted in the evaluation of paravertebral muscles and rectus abdominis muscles in a maximum isometric voluntary contraction test (MVC) during trunk extension movements, starting from the sitting position. Moreover, the Roland-Morris functional evaluation questionnaire and the Corlett and Manenica diagram for painful areas were used. An electromyograph with 16 pre-set channels was used. Signals were processed in time $\left(\mathrm{EMG}_{\mathrm{ME}}\right)$ and spectral $\left(\mathrm{EMG}_{\mathrm{MF}}\right)$ domains, using the MatLab ${ }^{\circledR}$ program. The Shapiro-Wilk test and Wilcoxon Signed Ranks Test were applied. Statistical analyses were performed through the SPSS v21.0 software and Microsoft Office Excel 2010, considering $p<0.05$ as significance level. Results: Results showed statistical differences in the post-working day for time analysis, an $\mathrm{EMG}_{\mathrm{ME}}$ decrease in the right rectus abdominis muscle $(\mathrm{p}=0.016)$ and in the age-stratified sample, with individuals over 31 years old $(\mathrm{p}=0.016)$; in the spectral analysis, $\mathrm{EMG}_{\mathrm{MF}}$ reduction in the right iliocostalis $(\mathrm{p}=0.027)$ and right and left side in the stratified sample, in individuals over 31 years old and with more than 10 years of service. Conclusion: The used protocol highlighted a decrease in the amplitude of the electromyographic signal, as well as possible muscle fatigue on the right side where officers usually carry their weapons.
\end{abstract}

Keywords: Electromyography, Military police officers, Spine, Bulletproof vest.

\section{Introduction}

The World Health Organization (WHO) recognizes that some professional classes present higher risks of developing clinical and pathological disorders due to their job (National..., 1997; Vanícola et al., 2010). The risk is higher due to peculiar occupational characteristics in which that workers are included, such as lack of regulatory norms peculiar to this activity and physical requirement (Reis, 2006). Thus, it is understood that military police officers are among the groups at risk of developing pain

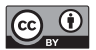

This is an Open Access article distributed under the terms of the Creative Commons Attribution License, which permits unrestricted use, distribution, and reproduction in any medium, provided the original work is properly cited.

How to cite this article: Santos MC, Krueger E, Neves EB. Electromyographic analysis of postural overload caused by bulletproof vests on public security professionals. Res Biomed Eng. 2017; 33(3):175-184. DOI: 10.1590/2446-4740.09016.

*Corresponding author: Brazilian Army Research Institute of Physical Fitness, Av. João Luis Alves, s/n ${ }^{\circ}$, Fortaleza de São João, Urca, CEP 22291-090, Rio de Janeiro, RJ, Brazil. E-mail: borbaneves@ hotmail.com

Received: 18 December 2016 / Accepted: 30 June 2017 complaints and work-related diseases. This is because military police (MP), during their working activities, are exposed to different overload conditions, such as the use of personal protective equipment like bulletproof vests and gun belts, and the adoption of inadequate postures during their working day (Tavares et al., 2014).

Military Police work is an activity exclusively carried out by military police officers; generally, tasks are executed in a visible way, that is, by a uniformed military police officer. Therefore, they carry all mandatory safety items, that is, bulletproof vests and gun belts. One of the modalities is motorized patrol, which is performed with the use of a vehicle. The sitting position in the vehicle is stressful due to 12 -hour shifts, and this may be aggravated by some factors: prolonged inadequate postures, age, professional habits and lack of physical activity (Claus et al., 2008).

Studies on bulletproof vests and belts highlight that your constant use imposes a physical overload influencing the performance of your labour activity (Rocha, 2008; Vasconcelos, 2007). Another problem is that bulletproof vests do not present any ergonomic adjustment to the 
officer's body, thus increasing the sensation of discomfort which, together with stress and fatigue - characteristics that are inherent to the target activity - may characterize factors jeopardizing their performance, such as reflex and speed decrease, which are fundamental for officers in incidents like shootings (Rocha, 2008).

The work situations to which military police officers are exposed require inadequate postural standards that may overload the musculoskeletal system of the spine, leading to the development of back pain (Konitzer et al., 2008). Lumbar pain is the most common symptom among individuals that present back pain (Tavares et al., 2014). Functional limitations caused by lumbar pain remove police officers from operational activities, and this is the main cause of working day losses and removal to administrative functions (Laat, 2005).

Commonly, evaluations to diagnose lumbar pain are based on subjective evaluations, through questionnaires and scales that only provide qualitative results (Bento et al., 2009). With the development of health technology, evaluation methods with quantitative indicators can be used, as electromyography (EMG), isokinetic dynamometry and an electrogoniometer providing stronger evidences in studies with variables that were previously evaluated only by qualitative methods.

The EMG provides quantitative data about the muscle electrical activity standard, defining in an objective way the number of motor unit recruitment (Miura and Sakuraba, 2014). Therefore, this work aimed to verify the electromyography response in operational military police officers (with overload of $5.7 \mathrm{~kg}$ from equipment) before and after a cycle of two working days. Electromyography as a tool for evaluation can provide quantitative results, such as a reduction in $\mathrm{EMG}$ frequency after the work shift, as well as decrease in EMG amplitude at the Erector muscle of the spine, after maximum isometric voluntary contraction test (MVC), indicating the presence of fatigue (Tarata, 2003), and associate them to the already used subjective methods.

\section{Methods}

This research may be classified as descriptive, because its goal is to describe the characteristics of a certain population or phenomenon, or to determine relations between variables; its characteristic is standardized data collection. This research was conducted in accordance with the ethical recommendations of Resolution n. 466/2012 issued by the National Research Ethics Committee of the Universidade Tecnológica Federal do Paraná, under protocol \#1.017.395.

The population was constituted by military police officers from Paraná state, representing, in actual data, a total of 21,000 state military officers. The military units where the research was conducted were the $20^{\text {th }}$ and $22^{\text {nd }}$ Military Police Battalions. Researchers received authorizations from the competent units.

The sample was composed by a total of 44 military police officers. The recruitment of volunteers occurred according to their availability, that is, the researcher went to the battalion and the officers on duty were invited to participate.

Officers complying with inclusion and exclusion criteria were informed about the research and they could choose if they wanted to participate or not; in case they accepted, they signed an Informed Consent Term and an Audio/Video Recording Consent Form.

As inclusion criteria, all officers had to be male and carrying out patrol activities, that is, they had to use all mandatory safety equipment. As exclusion criteria, there were officers having chronic or disabling disease, being obese or having recently undergone a surgery (less than 6 months).

Being a group of military police officers, none of them were identified in any way. Voluntariness was totally preserved, and they could quit the study at any moment.

\section{Pre-collection evaluation and volunteer preparation}

After signature of the ethical terms, the following data were collected: age, service time and whether they practiced any physical activity or not. The volunteer then filled out a Roland-Morris Questionnaire, an instrument of self-assessment and perception of difficulties in carrying out work and daily-life activities. The questionnaire contained 24 alternatives (yes or no), varying from zero (no disability) to 24 (severe disability), describing daily and work situations, which may be compromised by lumbar pain. Every Military Police Officer was instructed to check all alternatives that perfectly corresponded to their current physical condition. The choice of this instrument is due to the fact that it is internationally recognized and validated as a helping instrument in the investigation of lumbar pain symptoms (Johnston et al., 2004). The higher the number of checked alternatives, the worse the physical condition of the officer. Concomitantly to the questionnaire, the volunteer indicated on the Corlett and Manenica Diagram the painful areas related to the pain sensation at the moment of the evaluation.

After the initial evaluation, the evaluator requested that the officer took off his bulletproof vest, gun belt and uniform shirt, so that she could prepare the skin for electrode positioning. Skin preparation consisted in trichotomy and asepsis with $70^{\circ}$ alcohol; after positioning the electrodes, the evaluated person was photographed so that possible observations and corrections in the electrode position could be performed. 
The electromyography will be in this study with the goal of providing data collected by the test of maximum isometric voluntary contraction, performed before and after the officer's shift, who will be able to indicate changes in pain intensity in the Corlett and Manenica diagram for painful areas and in the Roland-Morris questionnaire on lumbar pain, where he will be able to indicate if the overload caused by the bulletproof vest changed; all this is made in order to later analyze the collected data in a statistical way.

\section{Electromyographic evaluation}

An EMG System do Brasi ${ }^{\circledR}$ equipment was used, $1600-\mathrm{U} 12$ model, with 16 channels and $3 \mathrm{M}^{\circledast} \mathrm{Ag} / \mathrm{AgCl}$ surface electrodes, in bipolar configuration, positioned according to the fiber orientation of the analyzed muscles. The reference electrode was located on the $\mathrm{C} 7$ spinous process. The channel to get the EMG signal was set to a sampling frequency of $1 \mathrm{kHz}$.

The placement of surface electrode pairs was performed according to the SENIAM protocol (Surface Electromyography for the Non-Invasive Assessment of Muscles), being held the desired muscle palpation and then positioning the electrodes. The same position of the electrodes was adopted in the two collections. For the trichotomy of the evaluated regions, procedure gloves and individual disposable razor blades were used; the skin was cleaned with sterilized cotton and alcohol for better adherence and fixation of the electrodes, which were spaced $2.5 \mathrm{~cm}$ apart.

The EMG channels were numbered and identified with the following sequence: 1: Right trapezius, 2: Left trapezius, 3: Erector spinae right side, 4: Erector spinae left side (both in the thoracic part), 5: Erector spinae right side, 6: Erector spinae left side (lumbar part), 7: Right rectus abdominis and 8: Left rectus abdominis.

The pairs of electrodes were aligned by anatomical markings such as bone and muscle belly accidents, as Figure 1.

\section{Collection protocol}

Collections occurred in the volunteers' workplace ( $20^{\text {th }}$ and $22^{\text {nd }}$ Battalions). Before performing the collections, the evaluator went to the battalion to explain the nature of the research and asked for a proper room to perform the collections. The room should respect at least minimum privacy, since the volunteer had to remove his shirt and it should have an electrical plug to turn on a heater when necessary, since some collections were performed early in the morning. Police officers were evaluated according to the sequence presented in Figure 2.

The evaluation of the paravertebral muscles in the sitting position is due to the fact that it simulates the

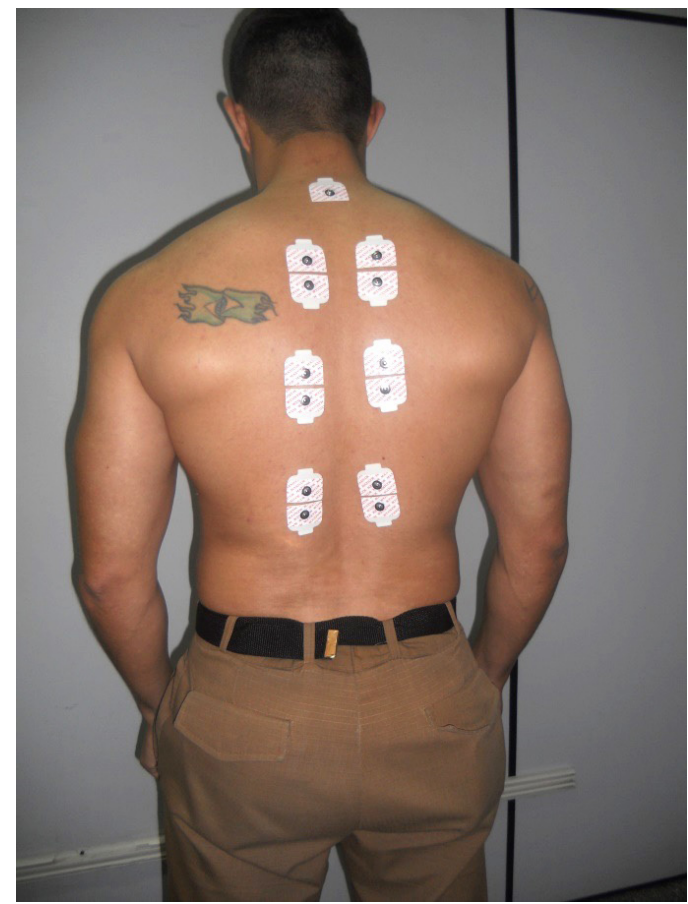

Figure 1. Posterior positioning of the electrodes.

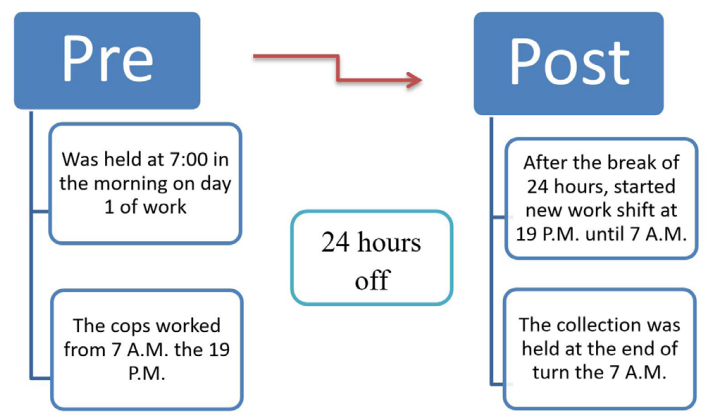

Figure 2. Study design: chronological line of data acquisition.

daily routine of the evaluated individuals because the same work sitting in police cars.

For the sitting position of the volunteers, a Quick Massagem chair was used, adapting it with a metal rod to fix a vest; this was placed on the individual to perform maximum isometric voluntary contraction test (MVC). Figure 3 shows the position of the volunteer on the adapted chair, observed on the side. To register EMG signals, two MVC were performed on the same day (where the signal with greater MVC was processed); in both of them, the volunteer performed a trunk extension with his maximum force for five seconds, with 2-minute intervals between the contractions. Inside this five seconds, between the $1.5 \mathrm{~s}$ initials and $1.5 \mathrm{~s}$ finals, $2 \mathrm{~s}$ to analysis window length were selected to process the signal. During tests, verbal support was given to guide volunteers. 


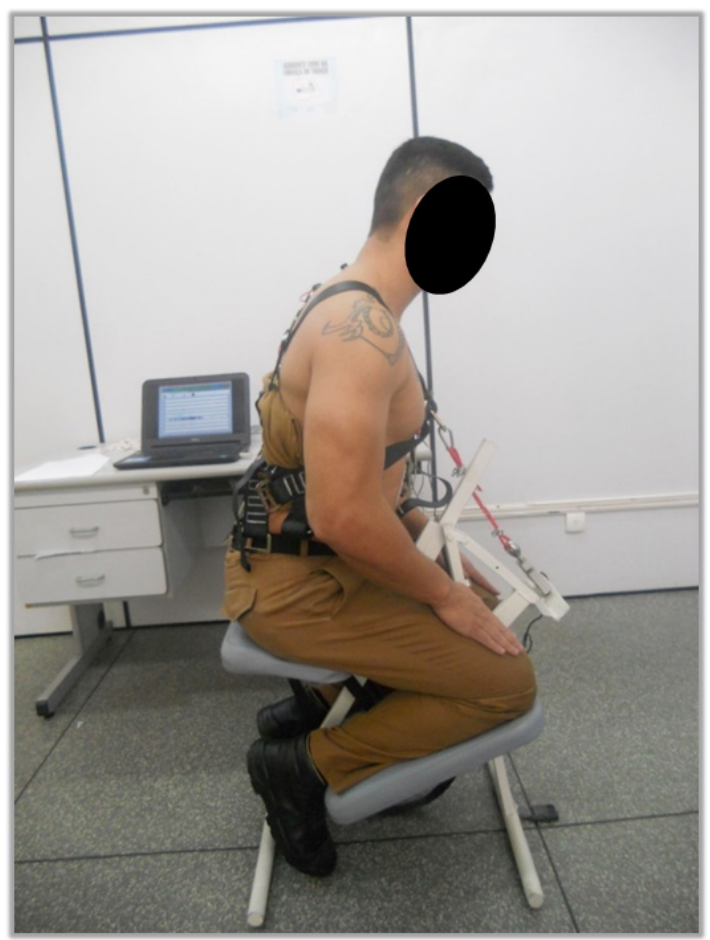

Figure 3. Volunteer position

\section{Data analysis}

This study obtained results from subjective evaluations through the Roland-Morris Questionnaire and the Diagram for painful areas and from objective evaluations through EMG signals; thus, a specific treatment was applied for each kind of generated data. Data referring to EMG were recorded and exported to an EMG system computer database.

\section{Processing}

Signals were analyzed in the spectral (median frequency $\left(\mathrm{EMG}_{\mathrm{MF}}\right)$ ) and time domain (median energy $\left(\mathrm{EMG}_{\mathrm{ME}}\right)$ ). We used median energy (that is related with root mean square feature) due to characteristic of non-parametric signal. A custom routine was generated with the MatLab ${ }^{\circledR}$ program. Signals were filtered with a $30-450 \mathrm{~Hz}$ third order bandpass Butterworth filter. The median frequency was processed by means of the Fast Fourier Transform, in accordance to Equation 1.

$$
M F=\int_{0}^{M F} P(f) d f=\frac{1}{2} \int_{0}^{f s} P(f) d f
$$

where MF is the median frequency, $P(f)$ is the power spectrum and fs the sampling rate.

The processing of EMG signals in time domain was performed using the absolute (or rectified) median amplitude equation, as presented in Equation 2. The median energy feature is a non-parametric data related with root mean square feature.

$$
M E_{E M G}=\frac{1}{2}\left(\left|E M G_{\text {signal }}\right|_{\frac{n}{2}}+\left|E M G_{\text {Signal }}\right|_{\frac{n}{2}+1}\right)
$$

where MF is the median energy (median of absolute amplitude), EMG is the electromyographic signal and $\mathrm{n}$ is the data analysis time frame.

\section{Statistical analysis}

For the statistical analysis, data registered on the right and left side were compiled and exposed on the same graph. Initially, signals were tested in terms of distribution normality by the Kolmogorov-Smirnov and Shapiro-Wilk tests, and EMG variables presented non-Gaussian distribution. In order to verify significant differences among results, the non-parametric Wilcoxon Signed Ranks Test was applied; results were inserted in individual tables related to each EMG parameter, energy median and median frequency, respectively. Results from the Roland-Morris functional evaluation questionnaire were analyzed by the Student's t test for independent samples, when compared to the sample subgroups. Statistical analyses were performed through the SPSS v21.0 software and Microsoft Office Excel 2010, considering $\mathrm{p}<0.05$ as significance level.

\section{Results}

Forty-four volunteers with an average age of $34.59 \pm 8.05$ participated in the study. Table 1 shows the analysis of data collected before the application of the protocol. It is possible to observe a discrepancy between the minimum and maximum age of the officers; this is because newly formed officers or officers with short service time are preferably assigned with more experienced officers.

Results from the Roland-Morris functional evaluation Questionnaire were separated by service time; in Figure 4 they are divided in 5 categories, every 5 years, up until the maximum limit of service for police officers, which is 35 years. There was no statistically significant difference among categories - the sample within categories can be a chance to explain the results.

When they were grouped in only 2 categories (less than 10 years and more than 10 years of service), a statistically significant difference was observed $(\mathrm{p}<0.05$ in the Student's t test for independent samples). The subjects with longer service time presented a significantly higher score (2.89) than the ones with less than 10 years of service (1.16). 
Table 1. Characterization of the sample: forty-four male military police officers.

\begin{tabular}{lccc}
\hline & $\begin{array}{c}\text { Minimum } \\
\text { (years) }\end{array}$ & $\begin{array}{c}\text { Maximum } \\
\text { (years) }\end{array}$ & $\begin{array}{c}\text { Mean } \\
\text { (years) }\end{array}$ \\
\hline Age & 20 & 51 & $34.59 \pm 8.05$ \\
Service time & 1 & 33 & $10.77 \pm 9.24$ \\
\hline
\end{tabular}

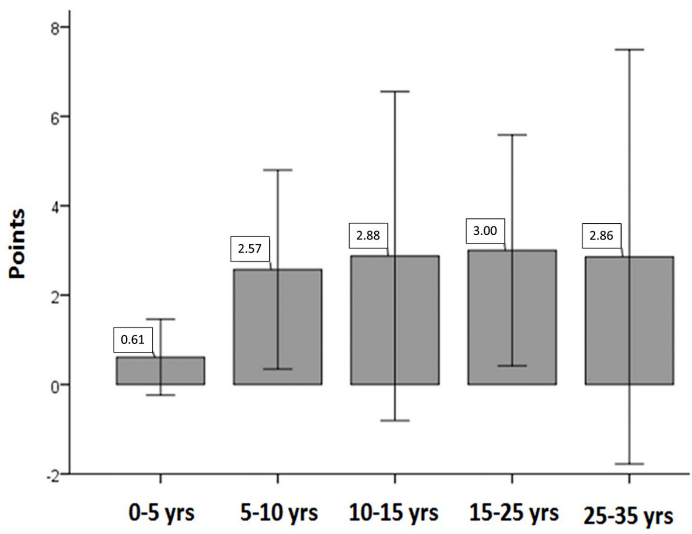

Figure 4. Distribution of the average score from the Roland-Morris questionnaire by five categories of service time in years (yrs) for 44 military police officers, 2015, Curitiba, PR, Brazil.
Results obtained by the diagram for painful areas were exposed in Figure 5. Each volunteer was oriented to mark the painful areas that accurately represented their current condition, regardless of the fact that the research was focused on the spine. The area that refers to the lower region of the spine was the most marked one, representing $50 \%$ of the total.

According to the protocol used in this research, the electromyographic records were performed twice, before and after the volunteer's working day. Table 2 presents the processing of the time and spectral domain and presented statistically significant differences in the frequency domain for the erector spinae, lumbar part on the right side; an $\mathrm{EMG}_{\mathrm{MF}}$ decrease was noticed after the working day $(p=0.027)$, It is assumed that postural overload caused by vest and holster may have been enough to reduce the speed of conduction of action. In the temporal domain, on the right side of the rectus abdominis muscle, an $\mathrm{EMG}_{\mathrm{ME}}$ decrease $(\mathrm{p}=0.016)$ was observed after the working day; this result corresponds to a lower muscle recruitment in the studied sample, verified by the MVC.

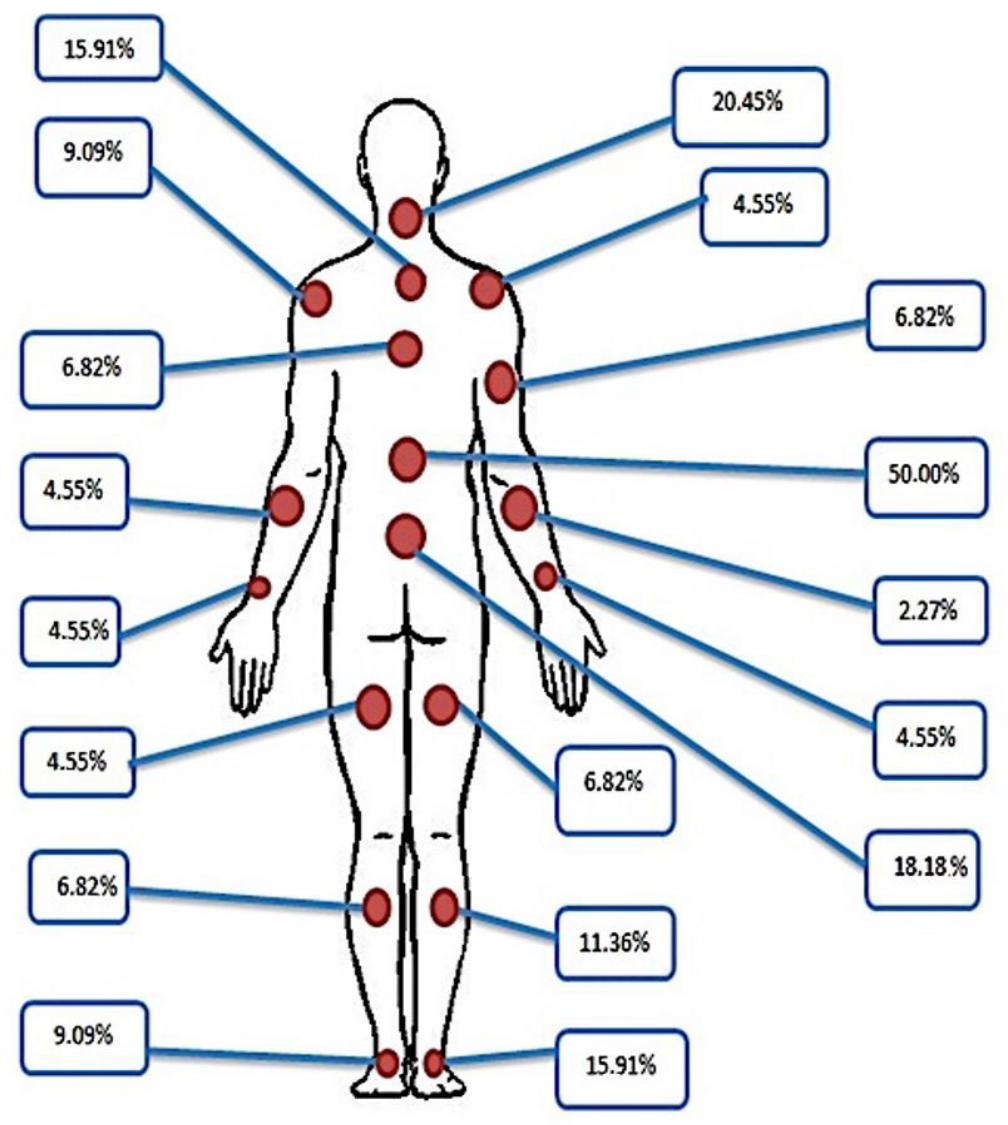

Figure 5. Marked positions of pain complaint (\%). 
Table 2. EMG parameter comparison for 44 military police officers, pre and post the working day, 2015, Curitiba, Brazil.

\begin{tabular}{|c|c|c|c|c|}
\hline & Median & IR & $\mathbf{Z}$ & p value \\
\hline Right trapezius $\mathrm{EMG}_{\mathrm{ME}}-$ pre $(\mu \mathrm{V})$ & 30.71 & 41.74 & \multirow{2}{*}{-0.388} & \multirow{2}{*}{0.698} \\
\hline Right trapezius $\mathrm{EMG}_{\mathrm{ME}}-$ post $(\mu \mathrm{V})$ & 31.03 & 47.26 & & \\
\hline Right trapezius $\mathrm{EMG}_{\mathrm{MF}}-$ pre $(\mathrm{Hz})$ & 106.50 & 25.50 & \multirow{2}{*}{-1.064} & \multirow{2}{*}{0.288} \\
\hline Right trapezius $\mathrm{EMG}_{\mathrm{MF}}-$ post $(\mathrm{Hz})$ & 97.50 & 26.00 & & \\
\hline Left trapezius $\mathrm{EMG}_{\mathrm{ME}}-$ pre $(\mu \mathrm{V})$ & 32.75 & 45.41 & \multirow{2}{*}{-0.275} & \multirow{2}{*}{0.783} \\
\hline Left trapezius $\mathrm{EMG}_{\mathrm{ME}}-$ post $(\mu \mathrm{V})$ & 33.34 & 35.78 & & \\
\hline Left trapezius $\mathrm{EMG}_{\mathrm{MF}}-$ pre $(\mathrm{Hz})$ & 109.50 & 20.00 & \multirow{2}{*}{-1.947} & \multirow{2}{*}{0.052} \\
\hline Left trapezius $\mathrm{EMG}_{\mathrm{MF}}-$ post $(\mathrm{Hz})$ & 100.00 & 34.50 & & \\
\hline Right erector spinae (lumbar) $\mathrm{EMG}_{\mathrm{ME}}-$ pre $(\mu \mathrm{V})$ & 107.50 & 29.50 & \multirow{2}{*}{-0.677} & \multirow{2}{*}{0.498} \\
\hline Right erector spinae (lumbar) $\mathrm{EMG}_{\mathrm{ME}}-$ post $(\mu \mathrm{V})$ & 31.72 & 31.83 & & \\
\hline Right erector spinae (lumbar) $\mathrm{EMG}_{\mathrm{MF}}-$ pre $(\mathrm{Hz})$ & 107.50 & 29.50 & \multirow{2}{*}{-2.207} & \multirow{2}{*}{0.027} \\
\hline Right erector spinae (lumbar) $\mathrm{EMG}_{\mathrm{MF}}-$ post $(\mathrm{Hz})$ & 102.00 & 22.00 & & \\
\hline Left erector spinae (lumbar) $\mathrm{EMG}_{\mathrm{ME}}-$ pre $(\mu \mathrm{V})$ & 28.24 & 29.53 & \multirow{2}{*}{-1.439} & \multirow{2}{*}{0.150} \\
\hline Left erector spinae (lumbar) $\mathrm{EMG}_{\mathrm{ME}}-$ post $(\mu \mathrm{V})$ & 32.32 & 32.30 & & \\
\hline Left erector spinae (lumbar) $\mathrm{EMG}_{\mathrm{MF}}-$ pre $(\mathrm{Hz})$ & 101.50 & 19.50 & \multirow{2}{*}{-0.765} & \multirow{2}{*}{0.444} \\
\hline Left erector spinae (lumbar) $\mathrm{EMG}_{\mathrm{MF}}-$ post $(\mathrm{Hz})$ & 102.50 & 24.00 & & \\
\hline Right erector spinae (thoracic) $\mathrm{EMG}_{\mathrm{ME}}-$ pre $(\mu \mathrm{V})$ & 19.74 & 37.33 & \multirow{2}{*}{-1.249} & \multirow{2}{*}{0.212} \\
\hline Right erector spinae (thoracic) $\mathrm{EMG}_{\mathrm{ME}}-$ post $(\mu \mathrm{V})$ & 17.01 & 18.14 & & \\
\hline Right erector spinae (thoracic) $\mathrm{EMG}_{\mathrm{MF}}-$ pre $(\mathrm{Hz})$ & 100.50 & 28.50 & \multirow{2}{*}{-1.281} & \multirow{2}{*}{0.200} \\
\hline Right erector spinae (thoracic) $\mathrm{EMG}_{\mathrm{MF}}-$ post $(\mathrm{Hz})$ & 92.00 & 28.00 & & \\
\hline Left erector spinae (thoracic) $\mathrm{EMG}_{\mathrm{ME}}-$ pre $(\mu \mathrm{V})$ & 15.16 & 12.91 & \multirow{2}{*}{-1.005} & \multirow{2}{*}{0.315} \\
\hline Left erector spinae (thoracic) $\mathrm{EMG}_{\mathrm{ME}}-$ post $(\mu \mathrm{V})$ & 16.20 & 24.89 & & \\
\hline Left erector spinae (thoracic) $\mathrm{EMG}_{\mathrm{MF}}-$ pre $(\mathrm{Hz})$ & 97.00 & 32.00 & \multirow{2}{*}{-0.942} & \multirow{2}{*}{0.346} \\
\hline Left erector spinae (thoracic) $\mathrm{EMG}_{\mathrm{MF}}-$ post $(\mathrm{Hz})$ & 96.50 & 26.00 & & \\
\hline Right rectus abdominis $\mathrm{EMG}_{\mathrm{ME}}-$ pre $(\mu \mathrm{V})$ & 4.91 & 5.34 & \multirow{2}{*}{-2.413} & \multirow{2}{*}{0.016} \\
\hline Right rectus abdominis $\mathrm{EMG}_{\mathrm{ME}}-$ post $(\mu \mathrm{V})$ & 3.54 & 3.05 & & \\
\hline Right rectus abdominis $\mathrm{EMG}_{\mathrm{MF}}-$ pre $(\mathrm{Hz})$ & 120.00 & 19.00 & \multirow{2}{*}{-0.727} & \multirow{2}{*}{0.467} \\
\hline Right rectus abdominis $\mathrm{EMG}_{\mathrm{MF}}-$ post $(\mathrm{Hz})$ & 123.00 & 21.00 & & \\
\hline Left rectus abdominis $\mathrm{EMG}_{\mathrm{ME}}-$ pre $(\mu \mathrm{V})$ & 3.51 & 7.51 & \multirow{2}{*}{-0.603} & \multirow{2}{*}{0.546} \\
\hline Left rectus abdominis $\mathrm{EMG}_{\mathrm{ME}}-$ post $(\mu \mathrm{V})$ & 4.39 & 4.05 & & \\
\hline Left rectus abdominis $\mathrm{EMG}_{\mathrm{MF}}-$ pre $(\mathrm{Hz})$ & 116.50 & 26.50 & -0.275 & 0.783 \\
\hline Left rectus abdominais $\mathrm{EMG}_{\mathrm{MF}}-$ post $(\mathrm{Hz})$ & 116.50 & 24.50 & & \\
\hline
\end{tabular}

IR - Interquartile range.

Table 2 shows that there was significant decrease (Wilcoxon Signed Ranks) in the electromyographic signal amplitude of the rectus abdominis $(\mathrm{p}=0.016)$ and of $\mathrm{EMG}_{\mathrm{MF}}$ of the erector spinae, right lumbar part $(\mathrm{p}=0.027)$ after the working day.

Analyses were performed with subgroups stratified by age and service time. Analyses were performed in the time and frequency domains. Significant differences between pre- and post-working day values were observed in groups with age over 31 , composed by 26 officers, and in the group with more than 10 years of service, with 20 subjects.

Table 3 compares the energy median of the rectus abdominis muscle. As for these results, it is possible to observe that there were significant differences $(p=0.016)$ in the $\mathrm{EMG}_{\mathrm{ME}}$ signal in the comparison between pre- and post-working day, on the right side.

Table 4 presents the values referring to the analysis of the erector spinae muscles, lumbar part, from subjects over 31 years old. There were significant differences, according to the Wilcoxon's test, in the $\mathrm{EMG}_{\mathrm{MF}}$ signal after the working day on the right and left side, with a decrease in the signal - on the right side: $118 \mathrm{~Hz}$ before the working day, $101.5 \mathrm{~Hz}$ after the working day, $\mathrm{p}=0.002$; on the left side: $105.25 \mathrm{~Hz}$ before the working day, $98.5 \mathrm{~Hz}$ after the working day, $\mathrm{p}=0.038$. This decrease may indicate possible bilateral muscle fatigue, in subjects older than 31 years of age.

Table 5 shows the results of the erector spinae muscles in subjects with more than 10 years of service. As for these results, it was observed that there were significant 
Table 3. Time analysis of the rectus abdominis muscle in subjects over 31 years old, from 26 military police officers, 2015, Curitiba, Brazil.

\begin{tabular}{lcccc}
\hline \multicolumn{1}{c}{ Median Energy $(\boldsymbol{\mu V})$} & Median & IR & Z & p value \\
\hline Right rectus abdominis - pre & 4.095 & 5.91 & -2.400 & $\mathbf{0 . 0 1 6}$ \\
Right rectus abdominis - post & 2.928 & 2.21 & & \\
\hline
\end{tabular}

IR - Interquartile range.

Table 4. Frequency domain analysis of the rectus abdominis muscle in subjects over 31 years old, from 26 military police officers, 2015, Curitiba, Brazil.

\begin{tabular}{lcccc}
\hline \multicolumn{1}{c}{ Median Frequency (Hz) } & Median & IR & Z & p value \\
\hline Right erector spinae (lumbar) - pre & 118 & 34.13 & \multirow{2}{*}{0.002} \\
Right erector spinae (lumbar) - post & 101.5 & 22.5 & 2.068 & \multirow{2}{*}{0.038} \\
\hline Left erector spinae (lumbar) - pre & 105.25 & 20.38 & -2.072 & \\
Left erector spinae (lumbar) - post & 98.5 & 12.63 & & \\
\hline
\end{tabular}

IR - Interquartile range.

Table 5. Frequency domain analysis of the rectus abdominis muscle in subjects with more than 10 years of service, from 20 military police officers, 2015, Curitiba, Brazil.

\begin{tabular}{lcccc}
\hline \multicolumn{1}{c}{ Median Frequency (Hz) } & Median & IR & Z & p value \\
\hline Right erector spinae (lumbar) - pre & 116.00 & 43.13 & -2.737 & 0.006 \\
Right erector spinae (lumbar) - post & 106.75 & 19.88 & 25.75 & -2.184 \\
\hline Left erector spinae (lumbar) - pre & 99.00 & 21.88 & \multirow{2}{*}{0.029} \\
Left erector spinae (lumbar) - post & 98.25 & &
\end{tabular}

IR - Interquartile range.

differences by Wilcoxon's test in the $\mathrm{EMG}_{\mathrm{MF}}$ signal, on both sides, after the working day - the Wilcoxon test showed $p=0.006$ and $p=0.029$ on the right and left side, respectively.

\section{Discussion}

In this study, it was possible to observe that $38.64 \%$ of the volunteers selected question number 2 in the Roland-Morris questionnaire ("I often change my position trying to keep my spine comfortable"). Postural discomfort during the working day was indicated as a risk factor for work-related diseases, as showed in the study conducted by da Trindade et al., where $75 \%$ of 262 military police officers with an average age of 37 , indicated through the questionnaire the presence of some osteomuscular disturbance; lumbar pain was the most frequent one (Trindade et al., 2015).

Another datum was found in the diagram for painful areas, where $50.00 \%$ indicated the medium region of the lumbar spine. Higher results were found in the study by Paulo (2010) using the same diagram, where the prevalence of found pain was $69.01 \%$ of 242 military police officers in the Military Police Academy in Barro Branco. The use of gun belts and bulletproof vests were mentioned by the evaluated subjects as the possible cause of that pain.

The incidence of lumbar pains was also reported in other studies with military police officers, being related to factors that are typical of the activity, such as the use of the bulletproof vests (Konitzer et al., 2008; Rocha,
2008; Vasconcelos, 2007) and the sitting posture during motorized patrol (Anderson et al., 2011; Donnelly et al., 2009; Paulo, 2010).

In this study, $54.55 \%$ of the evaluated individuals reported practicing physical activity. Military police service is considered one of the most stressful and tiring jobs for the individual, given that physical preparation becomes fundamental for a better performance of working activities (Berria et al., 2011). Physically more active individuals demonstrated to be more productive than the sedentary ones (Matos et al., 2010), being agreed that physical activity improves the functional ability of the individual (Rossi, 2012).

In the study conducted by Matos et al. (2010), 31 military police officers aged between 30 and 39 presented positive levels of physical conditioning, highlighting that in a military environment, individuals carry typical loads such as ammunitions and arms; therefore, the strongest and more resistant ones will have more abilities to carry them.

Different results were found in the study by Paulo (2010), were among 138 military police officers with an average age of $29,49 \%$ did not practice any physical exercise. The same author underlines that the incentive to practice physical activities is vital to stay healthy and to perfection physical aptitude, due to the peculiarities of Military Police function.

The analysis of electromyographic parameters has been used as an effective tool to interpret the relation between the physical load used during a certain task and occupational activity (Borges, 2013). 
The decrease of $\mathrm{EMG}_{\mathrm{MF}}$ as a result the fatigue may be associated with the type of muscle fiber recruited in the muscles evaluated during a particular activity (Barbosa and Gonçalves, 2005). Lumbar pain leads to spinal deconditioning; it fatigues muscles and creates muscle unbalance, limiting daily activities and causing type I muscle fiber atrophy (Kawano et al., 2008). Therefore, the more affected paravertebral muscles are, the less these muscles are used, resulting in abnormal trunk movements and increasing the chances of ligament and intervertebral discs injuries (Barbosa and Gonçalves, 2013b; Paulo, 2010). This functional limitation of paravertebral muscles generates an excessive overload in the lumbar area (Barbosa and Gonçalves, 2013c). The reduction of paravertebral muscle action as a cause for plastic deformation of capsules, ligaments and intervertebral discs due to the excessive overload imposed on these passive elements, will produce injuries on these distension vulnerable structures and will generate pain in the lumbar area (Barbosa and Gonçalves, 2005; Barbosa and Gonçalves, 2013a; Barbosa et al., 2010).

After the working day, a decrease in the average MF value was observed for the erector spinae (lumbar) on the right side. Gonçalves and Pereira (2009) found a decrease in the amplitude of the EMG signal in the erector spinae muscles in MVC test after 1 min of $15 \%$ body weight lifting task, although none difference in $\mathrm{EMG}_{\mathrm{MF}}$, that differs from our study possible due other muscles groups compensation during the task. An $\mathrm{EMG}_{\mathrm{MF}}$ decreases reveals type I peripheral fatigue (Kawano et al., 2008), which in this study is manifested as a reduction in $\mathrm{EMG}_{\mathrm{ME}}$ from 107.50 to $31.72 \mu \mathrm{V}$ although with no statistical significance. With fatigue presence, there is an accumulation of lactic acid, $\mathrm{H}^{+}$ions in sarcolemma and muscle fiber (Miura and Sakuraba, 2014; Ritvanen et al., 2007); this change in ion concentration brings a change in the excitability of muscle cell membrane (Candotti et al., 2008). This promotes a decrease in the conduction speed of muscle fiber, that is a decline in the propagation speed of the action potential (Gonçalves and Silva, 2007).

In this study, we also observed MF decrease in the erector spinae muscles, lumbar part, bilaterally after the working day of subjects over 31 years old and with more than 10 years of service. The current consideration of electromyography studies is to examine why the decline came about as the median frequency during fatigue (Borges, 2013). This result can be explained by the fact that the military police officer sitting in the car with the equipment, the fact that he is with the equipment can modify the posture in which it sits, in the specific case of this study since the subjects were sitting can be the volume of the weapon and ballistic vest may have changed the position with the guy sitting in the seat of the vehicle and this added to a possible unpreparedness of the paravertebral muscles may have led to changing the values of power and frequency. According to
Barbosa et al. (2010), there is a relation between this EMG parameter and the erector spinae muscle that is contralateral to the subject's manual dominance, because the muscle present lower fatigue propensity when compared with the ipsilateral muscle, as a result of the automatic practice induced to the erector spinae muscle through AVD's, which are mainly performed with the dominant upper limb (Barbosa et al, 2010).

One of the peculiarities of the military career is the fact that it begins starting from 18 years old; therefore, an over 31 years old subject already has more than 10 years of service, that is, this overload postural condition on capsules, ligaments and intervertebral discs has been persisting in these subjects for more than 10 years, causing functional damage to the spine (Barbosa and Gonçalves, 2005). Because of the great demand imposed on the spine by the target activity peculiarities of the Military Police, the erector spinae muscles may become less effective and there may be a decrease in the isometric ability of these muscles as a response to the postural overload.

In this study, it was possible to observe a decrease in the value of the rectus abdominis muscle energy median, on the right side, after the working day of the evaluated subjects $(\mathrm{p}<0.016)$. A possible explanation for the decreased number of motor unit recruitment is related to the lower demand for dynamic stabilization of the lumbopelvic region by this muscle in the sitting position; its motor activity is adjusted according to the position and the load imposed to the trunk (França et al., 2010; Hall et al., 2009; Silva et al., 2004). A decrease was also found in the energy median value in the referred muscle, in subjects over 31 years old, suggesting that with time and abnormal stress on the lumbar region, there would be lower activation of the abdominal muscles (Rossi, 2012).

It can be cited as limitations of this study: the lack of a control group and the "loss" of the Maximum Voluntary Isometric Contraction Torque (MVICT) values, because these values were acquired, but the authors observed that the baseline values presented many variations, i.e. the load cell was not reliable. Therefore, these data were not used.

This work aimed at verifying the electromyographic response in paravertebral muscles of operational military police officers before and after the working day, based on the need for searching a better understanding of the lumbar pain and postural overload among military police officers, as well as using tools to evaluate them. Based on our findings, it is possible to conclude that:

a) The thoracolumbar region was the one presenting the highest number of professionals with pain complaints (50\%), and regarding the functional alteration of the spine due to pain complaints, significant differences were found in subjects with more than 10 years of service; 
b) In time analysis by energy median, the variation of EMG signal in the studied muscles presented a decrease with significant differences only in the right rectus abdominis muscle after the working day and in the age stratified sample $(\mathrm{p}=0.016)$;

c) In the spectral analysis by median frequency, the EMG signal variation presented significant difference with signal decrease only in the erector spinae muscle - lumbar part, on the right side for the total sample $(p=0.027)$ and on the right and left side in the stratified sample, in subjects over 31 years old and with more than 10 years of service, suggesting that the intensity and duration of the muscle demand unable a possible muscle fatigue where officers usually carry their arms.

\section{References}

Anderson G, Zutz A, Plecas D. Police officer back health. The Journal of Criminal Justice Research. 2011; 2(1):1-17.

Barbosa FSS, Almeida CCR, Gonçalves M. Análise espectral do sinal eletromiográfico do músculo eretor da espinha obtido do teste de Sorensen. Fisioterapia em Movimento. 2010; 26(2):57583. http://dx.doi.org/10.1590/S0103-51502010000400008.

Barbosa FSS, Gonçalves M. Análise da fadiga dos músculos eretores da espinha por meio da amplitude do sinal eletromiográfico durante contrações submáximas realizadas no teste de Sorensen. ACTA Brasileira do Movimento Humano. 2013a; 3(4):1-16.

Barbosa FSS, Gonçalves M. Atividade eletromiográfica de músculos lombares durante contrações isométricas submáximas: um estudo cinesiológico. Revista Terapia Manual - Posturologia. 2013b; 11(53):389-94.

Barbosa FSS, Gonçalves M. Comparação entre protocolos de exaustão e de 30 segundos utilizados na avaliação da fadiga eletromiográfica dos músculos eretores da espinha. Brazilian Journal of Physical Therapy. 2005; 9(1):77-83.

Barbosa FSS, Gonçalves M. Proposta de índice eletromiográfico para o treinamento de músculos lombares. Fisioterapia \& Saúde Funcional. 2013c; 2(2):27-33.

Bento AAC, Paiva ACS, Siqueira FB. Correlação entre incapacidade, dor-Roland Morris, e capacidade funcionalSF-36 em indivíduos com dor lombar crônica não específica. E-scientia. 2009; 2(1):1-18.

Berria J, Daronco LSE, Bevilacqua LA. Aptidão motora e capacidade para o trabalho de policiais militares do batalhão de operações especiais. Revista Salusvita. 2011; 31(2):89-104.

Borges FR. Análise eletromiográfica da postura do profissional de saúde no inícioe fim doexpediente de trabalho [dissertation]. Guaratinguetá: Universidade Estadual Paulista; 2013.

Candotti CT, Loss JF, Pressi AM, Castro FA, Torre M, Melo MO, Araújo LD, Pasini M. Electromyography for assessment of pain in low back muscles. Physical Therapy. 2008; 88(9):10617. PMid:18689609. http://dx.doi.org/10.2522/ptj.20070146.
Claus A, Hides J, Moseley GL, Hodges P. Sitting versus standing: does the intradiscal pressure cause disc degeneration or low back pain? Journal of Electromyography and Kinesiology. 2008; 18(4):550-8. PMid:17346987. http://dx.doi.org/10.1016/j. jelekin.2006.10.011.

Donnelly CJ, Callaghan JP, Durkin JL. The effect of an active lumbar system on the seating comfort of officers in police fleet vehicles. International Journal of Occupational Safety and Ergonomics. 2009; 15(3):295-307. PMid:19744371. http:// dx.doi.org/10.1080/10803548.2009.11076809.

França FR, Burke TN, Hanada ES, Marques AP. Segmental stabilization and muscular strengthening in chronic low back pain: a comparative study. Clinics. 2010; 65(10):1013-7. PMid:21120303. http://dx.doi.org/10.1590/S1807-59322010001000015.

Gonçalves M, Pereira MP. Levantamento manual de carga repetitivo de curta duração com e sem o uso de cinto pélvico: efeito sobre a atividade EMG normalizada por diferentes indicadores. Revista Brasileira de Cineantropometria e Desempenho Humano. 2009; 11(2):151-9.

Gonçalves M, Silva S. Análise de variáveis eletromiográficas durante contração isométrica fadigante. Salusvita. 2007; 26(1):39-51.

Hall L, Tsao H, MacDonald D, Coppieters M, Hodges PW. Immediate effects of co-contraction training on motor control of the trunk muscles in people with recurrent low back pain. Journal of Electromyography and Kinesiology. 2009; 19(5):763-73. PMid:18037309. http://dx.doi.org/10.1016/j. jelekin.2007.09.008.

Johnston C, Fernandes JG, Paglioli EB. Instrumentos utilizados para avaliar o estado funcional das pessoas com dor lombar. Scientia Medica. 2004; 14(2):170-5.

Kawano MM, Souza RB, Oliveira BIR, Menacho MO, Cardoso APRG, Nakamura FY, Cardoso JR. Comparação da fadiga eletromiográfica dos músculos paraespinhais e da cinemática angular da coluna entre indivíduos com e sem dor lombar. Revista Brasileira de Medicina do Esporte. 2008; 14(3):20914. http://dx.doi.org/10.1590/S1517-86922008000300010.

Konitzer LN, Fargo MV, Brininger TL, Reed ML. Association between back, neck, and upper extremity musculoskeletal pain and the individual body armor. Journal of Hand Therapy. 2008; 21(2):143-9. PMid:18436136. http://dx.doi.org/10.1197/j. jht.2007.10.017.

Laat E. Estudo de episódios lombálgicos e condições de trabalho em militares [dissertation]. Porto Alegre: Universidade Federal do Rio Grande do Sul; 2005.

Matos DG, Salgueiro RS, Mazini ML Fo, Rodrigues BM, Aidar FJ, Lima JRP. Perfil evolutivo do condicionamento aeróbio e da força em policiais militares. Revista Brasileira de Ciências da Saúde. 2010; 8(25):14-20.

Miura T, Sakuraba K. Properties of force output and spectral EMG in young patients with nonspecific low back pain during isometric trunk extension. Journal of Physical Therapy Science. 2014; 26(3):323-9. PMid:24707077. http://dx.doi.org/10.1589/ jpts. 26.323 . 
National Institute for Occupational Safety and Health. Musculoskeletal disorders and workplace factors: a critical review of epidemiologic evidence for work-related disorders of the neck, upper extremity, and low back. Cincinnati: NIOSH; 1997.

Paulo LFL. Perfil antropométrico e a aptidão física dos policiais militares do Estado de São Paulo. Revista ENAF Science. 2010; 5(1):23-23.

Reis GP. A engenharia de produção aplicada às organizações de serviços em segurança pública: um estudo exploratório [internet]. Rio de Janeiro: VivaRio Biblioteca Virtu@1; 2006. [cited 2017 Mar 4]. Available from: http://www. comunidadesegura.org.br/files/active/0/Gilberto_Protasio_ Engenharia_de_Produ\%C3\%A7\%C3\%A3o.pdf

Ritvanen T, Zaproudina N, Nissen M, Leinonen V, Hänninen O. Dynamic surface electromyographic responses in chronic low back pain treated by traditional bone setting and conventional physical therapy. Journal of Manipulative and Physiological Therapeutics. 2007; 30(1):31-7. PMid:17224353. http://dx.doi. org/10.1016/j.jmpt.2006.11.010.

Rocha ALS. Analise ergonômica do colete de proteção balística utilizado pela Policia Militar do Estado de São Paulo [internet]. São Paulo: Centro de Altos Estudos de Segurança da Polícia Militar do Estado de São Paulo; 2008. [cited 2015 Jan 3]. Available from: http:/www.policiamilitar.sp.gov.br/caes/artigos/ Artigos\%20pdf/Afonso\%20Luiz\%20Sanches\%20Rocha.pdf
Rossi TN. Efeitos do exercício físico sobre a lombalgia. Revista Brasileira de Prescrição e Fisiologia do Exercício. 2012; 5(26):163-9.

Silva CO, Battistella LR, Kavamoto CA, Lopes JAF, Vasconcelos JCP. Análise do ritmo lombar e pélvico durante a flexoextensão da coluna vertebral em duas condições de simulação de levantamento de carga em policiais militares saudáveis. ACTA Fisiátrica. 2004;11(3):117-24.

Tarata MT. Mechanomyography versus electromyography, in monitoring the muscular fatigue. Biomedical Engineering Online. 2003; 2(1):3. PMid:12625837. http://dx.doi.org/10.1186/1475925X-2-3.

Tavares AT No, Faleiro TB, Moreira FD, Jambeiro JS, Schulz RDS. Lombalgia na atividade policial militar: análise da prevalência, repercussões laborativas e custo indireto. Revista Baiana de Saúde Pública. 2014; 37(2):365-74.

Trindade APNT, Oliveira LCN, Santos BMO, Oliveira FB, Quemelo PRV. Symptoms of musculoskeletal disorders among police officers. Arquivos de Ciências da Saúde. 2015; 22(2):42-5.

Vanícola MC, Massetto ST, Mendes EF. Biomecânica ocupacional: uma revisão de literatura. Revista Brasileira de Ciências da Saúde. 2010; 2(3):38-44.

Vasconcelos I. Estudo ergonômico do colete à prova de balas utilizado na atividade policial [dissertation]. Bauru: Universidade Estadual Paulista; 2007. 